\title{
IMPLEMENTASI SISTEM INFORMASI RANCANGAN KERJA TAHUNAN PADA BADAN KESATUAN BANGSA DAN POLITIK KABUPATEN MURUNG RAYA
}

\author{
Bayu Pratama Nugroho', Ferdiyani Haris ${ }^{2}$, Kristo Andri Anugrahno ${ }^{3}$ \\ ${ }^{1,2,3)}$ Program Studi Sistem Informasi, STMIK Palangkaraya \\ Jln. G. Obos, No. I 14, Palangka Raya, Kalimantan Tengah \\ Email : bayupratamanugroho@yahoo.com, sabila006@gmail.com, kristo@gmail.com
}

\begin{abstract}
ABSTRAK
Badan Kesatuan Bangsa dan Politik Kabupaten Murung Raya adalah salah satu instansi pemerintahan yang bergerak dalam bidang kesatuan dan politik. Sebagai instansi pemerintahan yang bertanggung jawab dalam bidang kesatuan serta politik tingkat Kabupaten di Kalimantan Tengah, pengolahan data serta informasi haruslah cepat dan akurat khususnya dalam hal pengolahan data rancangan kerja tahunan yang saat ini dikerjakan. Pengolahan data rancangan kerja tahunan pada Badan Kesatuan Bangsa dan Politik Kabupaten Murung Raya saat ini masih menggunakan aplikasi perkantoran yang umum digunakan yaitu Microsoft Office Excel. Penggunaan aplikasi ini belum banyak meningkatkan efisiensi kerja terutama dalam pembuatan laporan, sehingga kebutuhan akses informasi secara terkomputerisasi merupakan salah satu solusi agar dapat memberikan laporan pengolahan data rancangan kerja tahunan dengan cepat dan akurat. Metode pengembangan sistem yang digunakan adalah menggunakan metode SDLC yang sudah dikembangkan dari model Waterfall, karena metode SDLC ini terdiri dari tahap-tahap yang memberikan kemudahan, jika pada satu tahap tidak sesuai atau mengalami kesalahan maka dapat kembali ke tahap sebelumnya. Tahapan desain sistem dan perancangan database yang digunakan mulai dari Diagram Konteks, DFD Level dan ERD yang menghasilkan suatu database untuk pembuatan program. Pengelolaan data menggunakan Microsoft Visual Basic 2010 serta Microsoft Access 2007 sebagai media penyimpanan data.

Kata Kunci: Sistem, Informasi, Sistem Informasi, Rancangan Kerja Tahunan, Bangsa dan Politik Kabupaten Murung Raya, SDLC.
\end{abstract}

\begin{abstract}
Badan Kesatuan Bangsa dan Politik Kabupaten Murung Raya is one of the government agencies engaged in unity and politics. As a government agency that is responsible for unitary affairs and politics at the district level in Central Kalimantan, data and information processing must be fast and accurate, especially in terms of data processing of the annual work plan that is currently being carried out. Processing of annual work plan data on Badan Kesatuan Bangsa dan Politik Kabupaten Murung Raya currently still using office applications that are commonly used, namely Microsoft Office Excel. The use of this application has not significantly improved work efficiency, especially in reporting, so the need for computerized access to information is one solution in order to be able to provide annual work design data processing reports quickly and accurately. System development method used is using SDLC method that has been developed from the Waterfall model, because this SDLC method comprises the steps of providing ease, if at one stage was not appropriate or has errors, it can be returned to the previous stage. Stages of system design and database design are used starting from the Context Diagram, DFD Level and ERD which produce a database for programming. Data management uses Microsoft Visual Basic 2010 and Microsoft Access 2007 as data storage media.

Keywords: Systems, Information, Information Systems, Annual Work Plans, Bangsa dan Politik Kabupaten Murung Raya, SDLC.
\end{abstract}

\section{PENDAhuluan}

Perkembangan kemajuan teknologi dan informasi saat ini komputer memegang peranan penting dalam kehidupan di masyarakat maupun pada dunia kerja baik di pemerintahan ataupun swasta, komputer terus berkembang baik dari segi perangkat keras (hardware) maupun perangkat lunak (software) (Euis, 2016). Media elektronik seperti komputer ini telah berkembang pesat di negara-negara maju seperti halnya di indonesia, ini disebabkan semakin tingginya tuntutan untuk menyelesaikan setiap permasalahan yang dihadapi secara cepat (Mayudho \& Supriyanto, 2020).

Penggunaan alat bantu yang berbasis komputer tidak diragukan lagi kemampuannya dalam melakukan pengolahan data, dan juga mempunyai ketelitian yang tinggi di bandingkan dengan pengolahan data secara manual (Asmaranti \& Andayani, 20l8). 
Bayu Pratama Nugroho, Ferdiyani Haris dan Kristo Andri Anugrahno. 2021 Implementasi Sistem Informasi Rancangan Kerja Tahunan Pada Badan Kesatuan Bangsa Dan Politik Kabupaten Murung Raya

Badan Kesatuan Bangsa dan Politik Kabupaten Murung Raya adalah salah satu intansi pemerintahan yang bergerak dalam bidang kesatuan dan politik. Sebagai intansi pemerintahan yang bertanggung jawab dalam bidang kesatuan serta politik tingkat Kabupaten di Kalimantan Tengah, pengolahan data serta informasi haruslah cepat dan akurat khususnya dalam hal pengolahan data rancangan kerja tahunan yang saat ini dikerjakan.

Pengolahan data rancangan kerja tahunan pada Badan Kesatuan Bangsa dan Politik Kabupaten Murung Raya saat ini masih menggunakan aplikasi perkantoran yang umum digunakan yaitu Microsoft Office Excel. Penggunaan aplikasi ini belum banyak meningkatkan efisiensi kerja terutama dalam pembuatan laporan, karena pada saat penginputan data yang begitu banyak bagian administratrator sering memasukkan data yang sama. Kejadian tersebut akan mengakibatkan data yang dihasilkan kurang efektif dan efisien, sehingga kebutuhan akses informasi secara terkomputerisasi merupakan salah satu solusi agar dapat memberikan laporan pengolahan data rancangan kerja tahunan dengan cepat dan akurat.

Berdasarkan latar belakang tersebut, maka penulis tertarik untuk melakukan penelitian dengan judul "Implementasi Sistem Informasi Rancangan Kerja Tahunan pada Badan Kesatuan Bangsa dan Politik Kabupaten Murung Raya".

\section{TINJAUAN PUSTAKA}

Penelitian ini dibuat berdasarkan referensi dari sejumlah penelitian yang ada di indonesia. Secara garis besar perkembangan teknologi informasi dalam berbagai bidang kehidupan mendorong manusia untuk memanfaatkan teknologi informasi. Teknologi informasi, dalam hal ini penggunaan komputer, membantu unit dalam pemerintahan agar pekerjaan dapat dilakukan dengan cepat dan tepat, serta dapat meminimalkan resiko kehilangan data yang rawan bagi pemerintahan (Parsaorantua et. al., 2017).

Perkembangan ini dimanfaatkan pula oleh pemerintah untuk mempermudah dan mempercepat pekerjaannya. Teknologi tersebut di kembangkan oleh Indarwati (2013) untuk mengatasi masalah yang ditemui di Kelurahan Karangturi Gresik yaitu tentang penyusunan rencana kerja anggaran, dengan adanya aplikasi ini penyusunan rencana kerja anggaran dapat memberikan kontribusi diantaranya yaitu menghasilkan aplikasi penyusunan rencana kerja anggaran pada Keluahan Karangturi yang dapat mencari data yang dibutuhkan dengan mudah, dapat memberikan kemudahan dalam proses penyusunan.

Sementara Pratiwi, Widodo, \& Kanthi (20/8) membuat dan mengimplementasikan program aplikasi untuk meningkatkan kinerja pemerintah desa sehingga memenuhi sasaran pembangunan dan transparansi kepada masyarakat.. Aplikasi ini menghasilkan sebuah Sistem informasi Penyusunan Rencana Kerja Pemerintah (RKP) Desa Bidang Pembangunan Infrastruktur Berbasis Web dapat melakukan pengolahan data perencanaan kegiatan pembangunan infrastruktur desa sesuai dengan hasil yang disepakati musyawarah desa dan hasil pengolahan data usulan perencanaan kegiatan pembangunan berupa dokumen Rencana Kerja Pemerintah Desa (RKP Des) untuk jangka waktu satu tahun.

Kemudian Bukhori (20II) melakukan analisis dan pengembangan lanjutan aplikasi sireka (sistem informasi rencana kegiatan dan anggaran) bagian penyusunan rencana badan pusat statistik. Hasil pengembangan ini dilakukan bertujuan agar aplikasi ini bisa mengakomodir perubahan data pembiayaan sehingga tidak mengubah data perencanaan tahun anggaran yang sudah dilaksanakan sebelumnya.

Berdasarkan penelitian-penelitian yang pernah dilakukan terkait rencana kerja tahunan, maka akan dilakukan penelitian yang membahas tentang sistem informasi rencana kerja tahunan. Penelitian ini diharapkan dapat menangani permasalahan-permasalahan yang mencakup rencana kerja.

\section{METODE PENELITIAN}

Metode penelitian yang digunakan adalah analisis dan pengembangan sistem (Analys reseach and development system). Analisis dan pengembangan sistem yaitu metode penelitian 
yang digunakan untuk menghasilkan produk tertentu dan menguji keefektifan dari produk tersebut (Mumpuni, \& Dewa, 2017). Pengembangan Sistem yang digunakan oleh penulis menggunakan metode SDLC (System Development Lyfe Cycle), yaitu suatu model pengembangan yang memiliki proses tahapantahapan pengerjaan yang dilakukan oleh analis sistem dalam membangun sebuah sistem informasi. Terdapat berbagai macam model pengembangan dalam SDLC, salah satunya adalah dengan Waterfall model atau Model Air Terjun untuk mengembangkan sistem yang dibuat (Rosa dan Shalahuddin, 2018).

Waterfall model menyediakan pendekatan alur hidup pengembangan perangkat lunak secara sekuensial atau terurut dengan dari tahapan sebagai berikut :

a. Perencanaan

Tahap ini penulis melakukan pengumpulan data yang bertujuan untuk menguraikan kebutuhan apa saja yang akan dibuat pada sistem sesuai dengan kebutuhan pengguna pada instansi terkait tempat penelitian.

\section{b. Analisis}

Tahap ini penulis menganalisa sistem untuk menemukan kelemahan-kelemahan yang terdapat pada sistem lama sehingga dapat diusulkan suatu perbaikan.

Di dalam tahap analisis sistem terdapat langkah-langkah dasar yang harus dilakukan oleh analis sistem yaitu sebagai berikut ini :

I) Identify, yaitu mengidentifikasi masalah. Pada penelitian ini masalah yang dihadapi oleh Badan Kesatuan Bangsa dan Politik Kabupaten Murung Raya dengan sistem lama adalah masih menggunakan aplikasi perkantoran yang umum digunakan yaitu Microsoft Office dalam pengelolaan data Program Kegiatan, pengelolaan data Sasaran Program Kegiatan kerja tahunan, pengelolaan data Pagu Anggaran Kegiatan, pengelolaan data Pencapaian Sasaran, pengelolaan data Indikator Sasaran Kegiatan serta pengelolaan data Realisasi Kegiatan.

2) Understand, yaitu memahami kerja dari sistem yang ada. Sistem yang sedang berjalan saat ini pada Badan Kesatuan Bangsa dan Politik Kabupaten Murung Raya adalah proses penginputan realisasi kegiatan, perhitungan masih dilakukan dengan cara menghitung manual kemudian diinputkan pada tabel serta dalam pengelolaan data program kegiatan masih menggunakan aplikasi perkantoran yang umum digunakan yaitu Microsoft Office Word sehingga sulit dilakukan pengecekan atau pembuatan laporan kegiatan pada tahun tertentu dikarenakan banyaknya file tempat pengetikan.

3) Analyze, yaitu menganalisis sistem. Analisis sistem dapat didefinisikan sebagai tahap penguraian dari suatu sistem yang dilakukan setelah tahap perencanaan sistem (systems planning) dan sebelum tahap desain sistem (systems design). Dalam tahapan analisis memiliki perbedaan dengan tahapan perencanaan, dimana dalam tahapan analisis lingkup tugasnya lebih terperinci. Penulis akan menganalisis bagaimana proses pengelolaan data rencana kerja tahunan pada Badan Kesatuan Bangsa dan Politik Kabupaten Murung Raya, apakah sistem sudah berjalan dengan baik, memahami alur kerja dalam pengelolaan proses pagu indikatif program kegiatan tahunan, mengidentifikasi kelemahan dari sistem pengelolaan data pencapaian sasaran kegiatan serta realisasi kegiatan dan penyusunan laporan akhir hasil analisis.

4) Report, yaitu membuat laporan akhir hasil analisis. Semua hasil yang didapat dari penelitian perlu dilampirkan pada laporan hasil analisis sehingga pengguna dapat memeriksa kembali data yang dihasilkan apakah sudah sesuai.

Dari analisis di atas dapat disimpulkan bahwa informasi yang dihasilkan menggunakan sistem yang ada memiliki cukup banyak kelemahan. Oleh karena itu maka penulis mengambil sebuah kesimpulan perlunya Badan Kesatuan Bangsa dan Politik Kabupaten Murung Raya untuk menerapkan sebuah sistem pengelolaan data secara terkomputerisasi yang dapat membantu untuk menanggulangi permasalahan yang ada sehingga semua kekurangan maupun kebutuhan informasi dan pembuatan laporan dapat teratasi.

c. Desain 
Bayu Pratama Nugroho, Ferdiyani Haris dan Kristo Andri Anugrahno. 2021 Implementasi Sistem Informasi Rancangan Kerja Tahunan Pada Badan Kesatuan Bangsa Dan Politik Kabupaten Murung Raya

Tahap ini penulis membuat desain sistem yang nantinya akan digunakan dengan menyesuaikan data yang didapat dari instansi terkait tempat penelitian, agar sistem dapat menghasilkan bentuk output yang sesuai kebutuhan pengguna dengan menggunakan Data Flow Diagram (DFD).

\section{d. Implementasi}

Tahapan ini merupakan proses pembuatan sistem yang akan digunakan pada penelitian berdasarkan kebutuhan pengguna yang telah dianalisa serta pengujian sistem yang dibuat menggunakan sistem pengkodingan Visual Basic NET 2010.

\section{e. Pengujian}

Tahapan ini penulis melakukan pengujian sistem apakah sistem yang dibuat sudah sesuai yang berjalan pada instansi terkait tempat penelitian dengan menggunakan Black Box Testing, serta melakukan perbaikan jika terdapat kesalahan pada sistem

\section{f. Perawatan}

Tahapan ini dilakukan perawatan (maintenance) baik itu tampilan, maupun perbaikan-perbaikan lainnya yang berhubungan dengan sistem serta melakukan scanning berkala terhadap virus yang mengganggu serta melakukan backup data.

\section{HASIL DAN PEMBAHASAN}

Pada bagian hasil dan pembahasan penulis menguraikan tahapan-tahapan yang berhubungan dengan implementasi aplikasi ini:

\section{A. Desain Sistem}

I) Diagram Konteks

Pada Diagram Konteks ini, terdiri dari I proses global dengan 2 buah entitas yang ada di luarnya yaitu Admin dan Kepala Badan BAKESBANGPOL. Pada entitas admin terhubung dengan sistem secara dua arah, dimana garis yang mengarah dari admin menuju proses sistem menunjukkan aktifitas admin berinteraksi dengan sistem yaitu melakukan login. Selanjutnya mengelola data yang meliputi data pengguna, data
Rencana, data Sasaran, data Program, data Indikator, data Pagu Indikatif Program, data Pencapaian Sasaran, data Realisasi, Backup dan Restore data serta Setting Tanda Tangan. Kemudian untuk garis balik dari sistem menuju ke admin menunjukkan bahwa admin memerlukan informasi mengenai data-data yang telah diproses oleh sistem dan memberikan respon balik berupa informasi yang telah diminta yaitu berupa validasi data login dan konfirmasi balik dari semua olahan data serta laporan yang kemudian diserahkan kepada Kepala Badan BAKESBANGPOL Murung Raya. Berikut gambar diagram konteks :

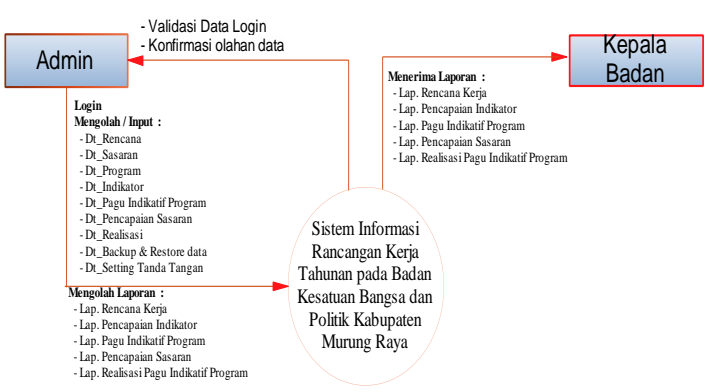

Gambar I. Diagram Konteks

2) Diagram Arus Data Level 0

Diagram arus data level 0 merupakan penjabaran proses lebih detail dari tahapan-tahapan proses yang ada pada diagram konteks yang menggambarkan alur sistem yang dibangun mulai dari data berasal sampai ke tempat penyimpanan data. Adapun prosesprosesnya yaitu 10 proses pengolahan data : proses I admin melakukan login sistem, proses 2 admin mengelola data Pengguna, proses 3 admin mengelola data Rencana, proses 4 admin mengelola data Sasaran, proses 5 admin mengelola data Program, proses 6 admin mengelola data Indikator, proses 7 admin mengelola data Pagu Indikatif Program, proses 8 admin mengelola data Pencapaian Sasaran, proses 9 admin mengelola data Realisasi, dan proses 10 admin mengelola cetak 
laporan. Berikut gambar diagram arus data level 0 :

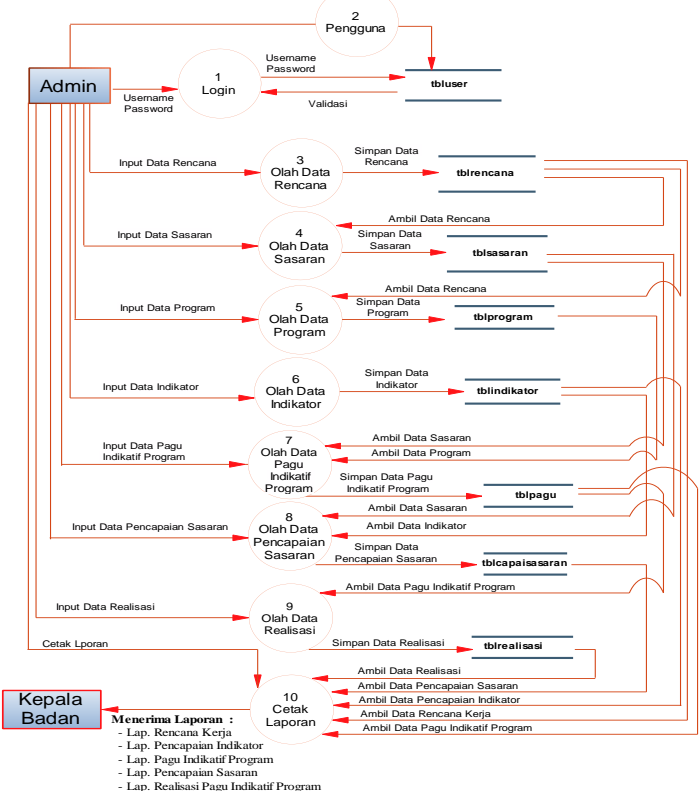

Gambar 2. DFD Level 0 Sistem Informasi Rancangan Kerja BAKESBANGPOL Murung Raya

3) Diagram Arus Data Level I Proses I Login Pada diagram gambar 3 menggambarkan bahwa admin melakukan login sistem dengan memasukkan data login ke sistem yang terdiri dari username dan password. Kemudian sistem akan melakukan validasi data, apabila data login yang dimasukkan tidak valid atau/tidak cocok maka sistem akan mengirimkan konfirmasi balik berupa pesan kepada admin bahwa username atau password salah. Apabila data username dan password benar maka admin dapat masuk dan mengakses sistem. Berikut gambar diagram arus data level I proses I login :

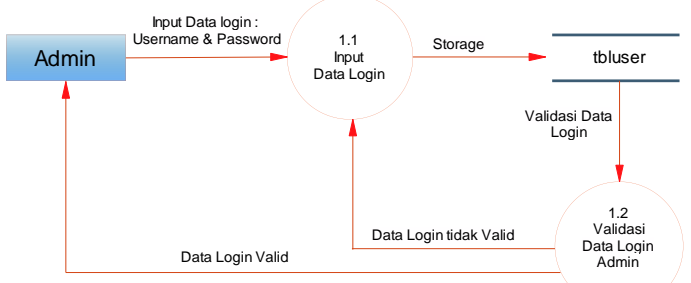

Gambar 3. Diagram Arus Data Level I Proses I Login

4) Diagram Level I Proses 2 Data Pengguna Pada gambar 4 menggambarkan bahwa proses 2.1 sampai 2.3 admin mengelola data pengguna dimana admin dapat melakukan tambah data, edit data maupun menghapus data pengguna.

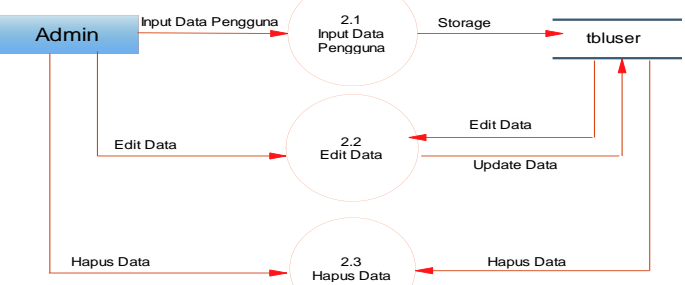

Gambar 4. Diagram Level I Proses 2 Data Pengguna

5) Diagram Level I Proses 3 Data Rencana

Pada gambar 5 menggambarkan bahwa proses 3.1 sampai 3.3 menjelaskan admin dapat mengelola data rencana kerja tahunan mulai dari tambah data, edit data dan menghapus data.

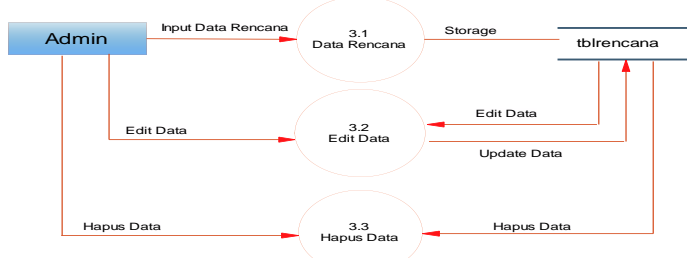

Gambar 5. Diagram Level I Proses 3 Data Rencana

6) Diagram Level I Proses 4 Data Sasaran

Pada gambar 6 menggambarkan proses 4.1 sampai 4.3 bahwa admin dapat mengelola data dengan melakukan tambah data, edit data maupun menghapus data. Untuk menginput data sasaran admin harus memanggil record data rencana.

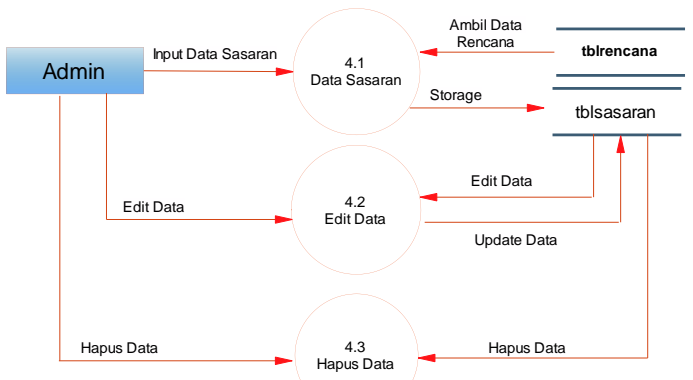

Gambar 6. Diagram Level I Proses 4 Data Sasaran

\section{7) Diagram Level I Proses 5 Data Program}

Pada gambar 7 menggambarkan bahwa admin dapat mengelola data program kegiatan rencana kerja dengan melakukan penambahan data, mengedit data maupun 
Bayu Pratama Nugroho, Ferdiyani Haris dan Kristo Andri Anugrahno.

menghapus data. Untuk menginput data sasaran admin harus memanggil record data program.

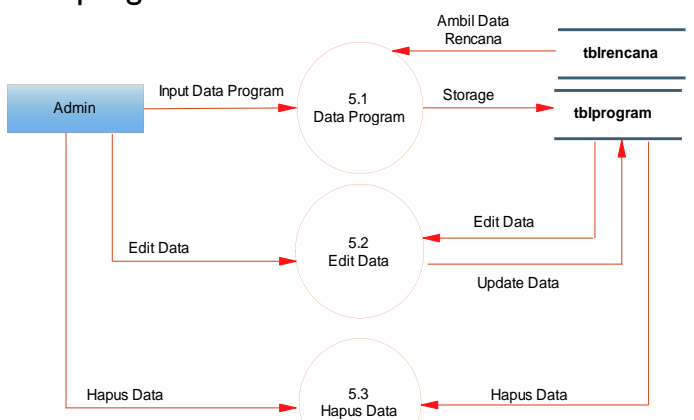

Gambar 7. Diagram Level I Proses 5 Data Program

8) Diagram Level I Proses 6 Data Indikator

Pada gambar 8 menggambarkan bahwa admin dapat mengelola data indikator dengan melakukan tambah data, edit data dan hapus data.

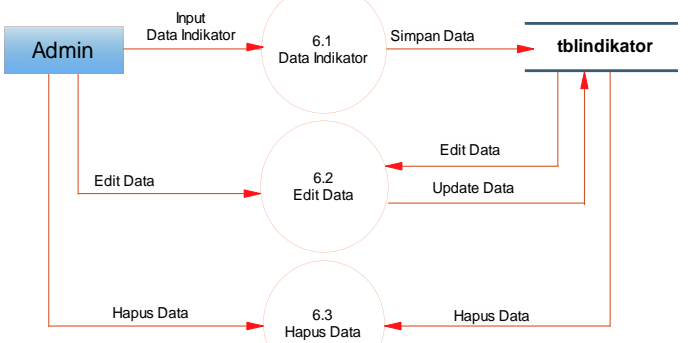

Gambar 8. Diagram Level I Proses 6 Data Indikator

9) Diagram Level I Proses 7 Data Pagu Indikatif

Pada gambar 9 menggambarkan bahwa admin dapat mengelola data anggaran dana pagu indikatif dengan melakukan tambah data dan menghapus data. Untuk menginput data pagu indikatif admin harus memanggil record data sasaran kegiatan dan record dari data program kegiatan.

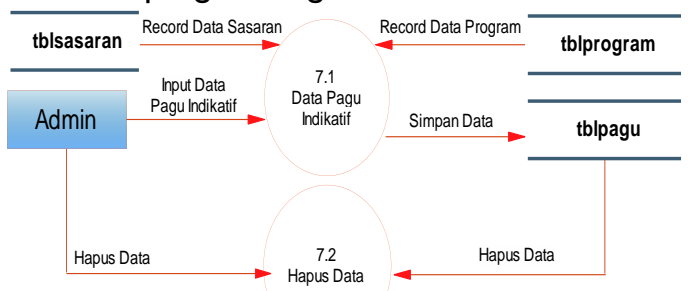

Gambar 9. Diagram Level I Proses 7 Data Pagu Indikatif

10) Diagram Level I Proses 8 Data Pencapaian Sasaran

Pada gambar 10 menjelaskan bahwa admin dapat mengelola data pencapaian sasaran dari program kegiatan yang telah diagendakan dengan melakukan penambahan data dan penghapusan data. Untuk menginput data pencapaian sasaran admin harus memanggil record dari data sasaran dan record data program.

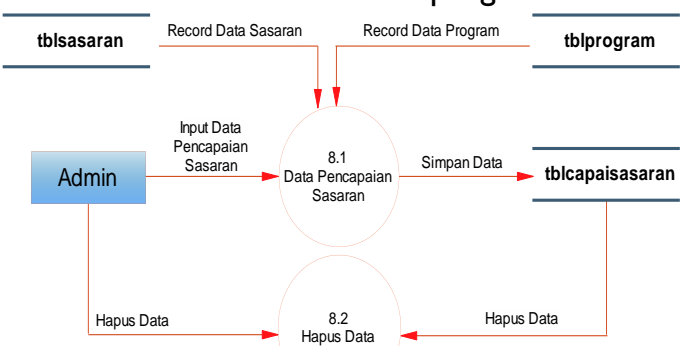

Gambar 10. Diagram Level I Proses 8 Data Pencapaian Sasaran

II) Diagram Level I Proses 9 Data Realisasi Pada gambar II menjelaskan bahwa admin dapat mengelola data realisasi kegiatan dengan melakukan penambahan data dan penghapusan data. Untuk menginput data realisasi admin harus memanggil record dari data pagu indikatif rencana program kegiatan.

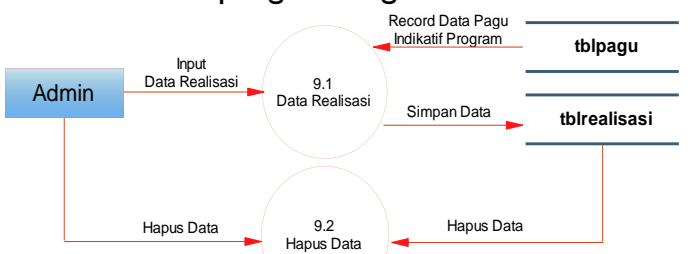

Gambar I I. Diagram Level I Proses 9 Data Realisasi

12) Diagram Level I Proses 10 Cetak Laporan

Pada gambar 12 menggambarkan bahwa admin dapat melakukan cetak laporan dimana pada proses 10.1 admin memilih laporan data yang hendak dicetak selanjutnya sistem akan memanggil record 
data dari penyimpanan data (database) sesuai dengan pilihan data yang hendak dicetak. Proses 10.2 data yang telah dipilih kemudian dicetak guna diserahkan kepada Kepala BAKESBANGPOL untuk dijadikan arsip/laporan yang terdiri dari Laporan Data Rencana Kerja, Laporan Data Pencapaian Indikator, Laporan Data Pagu Indikatif Program, Laporan Data Pencapaian Sasaran serta Laporan Data Realisasi Pagu Indikatif Program.

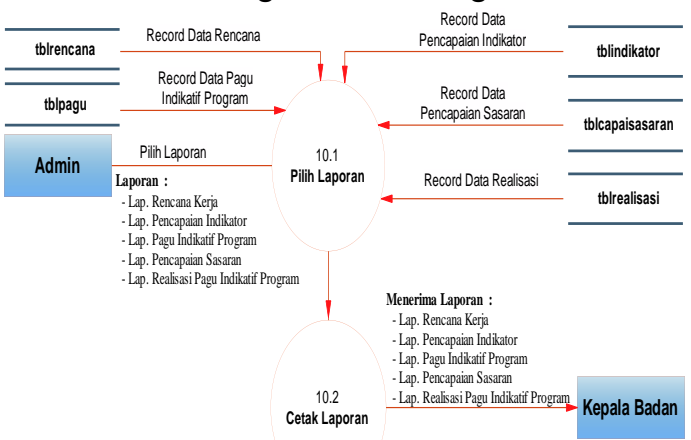

Gambar 12. Diagram Level I Proses 10 Cetak Laporan

\section{B.Desain Basis Data}

Dalam perancangan desain basis data diperlukannya entity relationship diagram (ERD) untuk memudahkan dalam membuat struktur tabel basis data. Di bawah ini adalah rancangan dari ERD Sistem Informasi Rancangan Kerja Tahunan pada Badan Kesatuan Bangsa dan Politik Kabupaten Murung Raya yang digambarkan sebagai berikut :

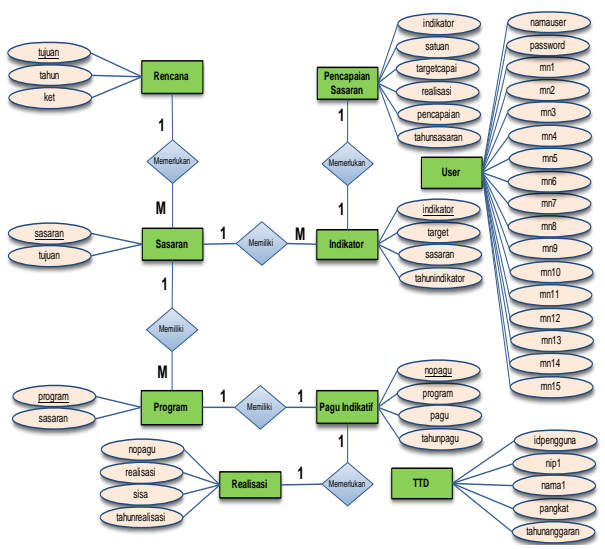

Gambar I3. ERD Sistem Informasi Rancangan Kerja Tahunan pada Badan Kesatuan Bangsa dan Politik Kabupaten Murung Raya

\section{Implementasi Aplikasi}

Adapun tahapan implementasi aplikasi pada "Sistem Informasi Rancangan Kerja Tahunan pada Badan Kesatuan Bangsa dan Politik Kabupaten Murung Raya" akan diuraikan sebagai berikut :

I. Form Login System

Login System adalah form pertama kali yang digunakan pengguna untuk mengakses aplikasi dengan memasukkan identitas nama user (username) dan kata sandi (password), disamping itu form login digunakan sebagai ijin pengamanan guna mendapatkan hak akses untuk masuk dan mengakses sistem. Tampilan form login dapat dilihat sebagai berikut :

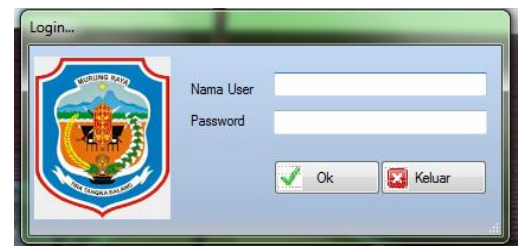

Gambar 14. Tampilan Form Login System

\section{Form Menu Utama}

Menu utama merupakan halaman awal yang akan ditampilkan pada saat membuka aplikasi setelah Form Login System. Menu utama ini digunakan sebagai penghubung untuk membuka form-form aplikasi untuk pengolahan data, mulai dari proses input sampai dengan cetak. Tampilan dapat dilihat sebagai berikut :

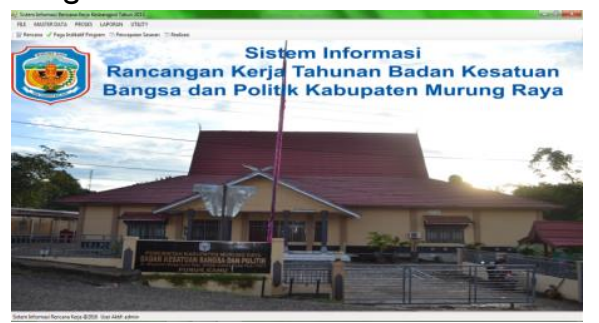

Gambar I5. Tampilan Form Menu Utama

\section{Form Rencana}

Form Rencana adalah form digunakan untuk mengolah data rencana kerja tahunan pada Badan Kesatuan Bangsa dan Politik Kabupaten Murung Raya. Pengolahan tersebut meliputi penginputan data, penghapusan data serta edit data. Untuk menambah data pada form tersebut, pengguna dapat memilih tombol "Tambah Rencana” pada Form View Rencana kemudian 
Bayu Pratama Nugroho, Ferdiyani Haris dan Kristo Andri Anugrahno. 2021 Implementasi Sistem Informasi Rancangan Kerja Tahunan Pada Badan Kesatuan Bangsa Dan Politik Kabupaten Murung Raya

memasukkan data pada form yang dipanggil. Untuk mengedit atau menghapus data pada form tersebut, pengguna dapat melakukan double click pada datagrid data yang ingin dihapus atau diedit. Tampilan form View Rencana dapat dilihat sebagai berikut :

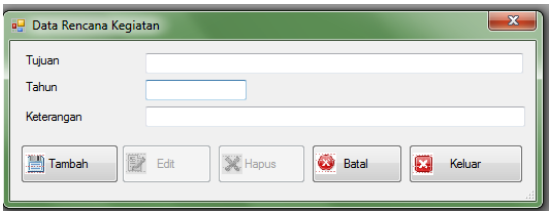

Gambar 16. Tampilan Form Rencana

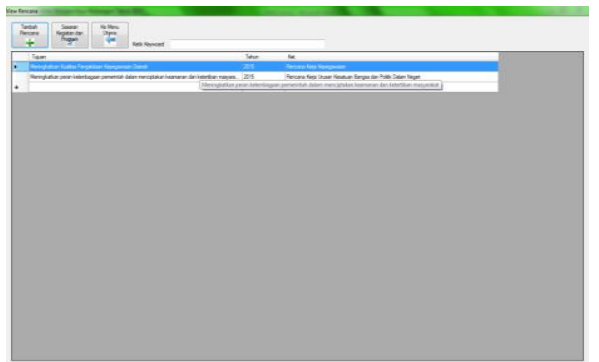

Gambar 17. Tampilan Form View Rencana

Untuk mencetak data rencana kegiatan yang telah tersimpan, pengguna dapat memilih pilihan "Laporan" pilih "Rencana Kerja" kemudian pengguna dapat menentukan data yang ingin dilihat atau dicetak dengan menentukan tahun dan bagian. Berikut adalah tampilan form proses untuk mencetak laporan data rencana kegiatan yang dapat dilihat pada gambar berikut :

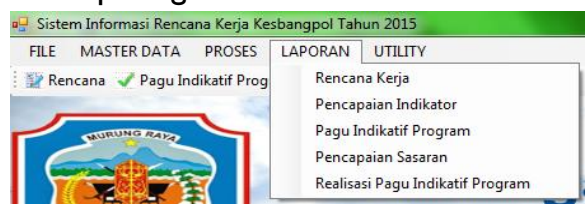

Gambar 18. Tampilan Form Proses Cetak Data Rencana Kegiatan

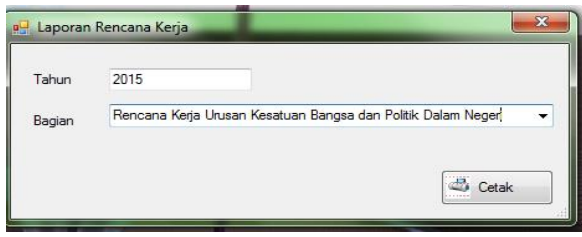

Gambar 19. Tampilan Form Proses Pemilihan Tahun dan Bagian Data Rencana Kerja
Berikut adalah contoh tampilan hasil laporan data Rencana Kegiatan berdasarkan pemilihan dari data tahun dan bagian :

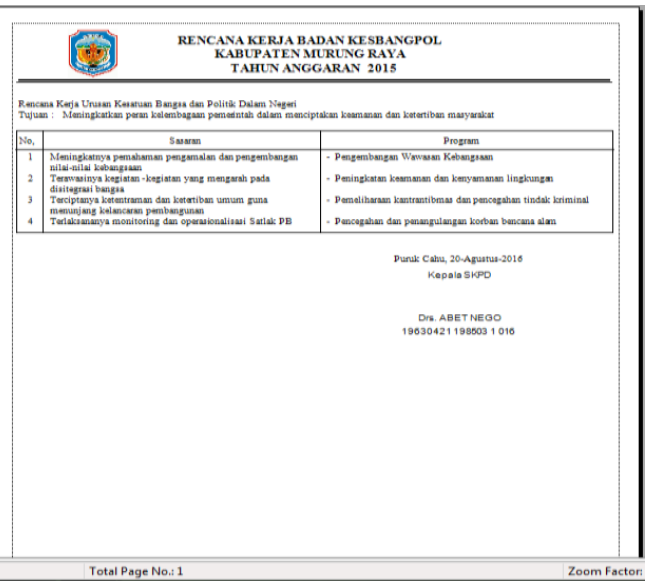

Gambar 20. Tampilan Laporan Data Rencana Kegiatan

\section{Form Sasaran}

Form Sasaran adalah form yang digunakan untuk mengolah data sasaran dari rencana kerja tahunan pada Badan Kesatuan Bangsa dan Politik Kabupaten Murung Raya. Pengolahan tersebut meliputi penginputan data, edit data dan hapus data. Untuk menambah data pada form tersebut, pengguna dapat memilih tombol "Sasaran Kegiatan dan Program" setelah melakukan double click pada datagrid kemudian memasukkan data pada form yang dipanggil. Untuk mengedit atau menghapus data pada form tersebut, pengguna dapat melakukan double click pada datagrid data yang ingin dihapus atau diedit. Tampilan form Sasaran dapat dilihat sebagai berikut :

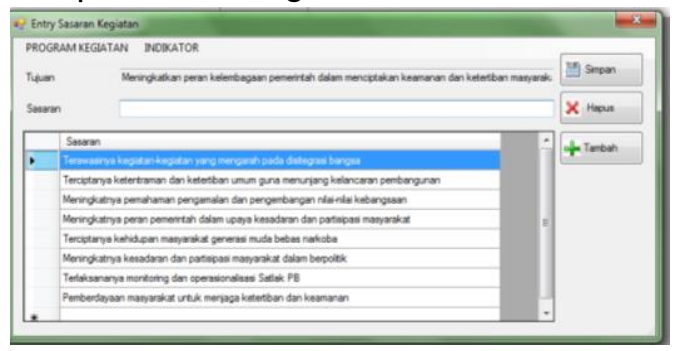

Gambar 21. Tampilan Form Data Sasaran

\section{Form Program Kegiatan}

Form Program Kegiatan adalah form yang digunakan untuk mengolah data program kegiatan yang direncanakan pada Badan 
Kesatuan Bangsa dan Politik Kabupaten Murung Raya. Untuk menambah data pada form tersebut, pengguna dapat memilih tombol "Sasaran Kegiatan dan Program" setelah melakukan double click pada datagrid klik data sasaran kegiatan pada datagrid kemudian memilih Label "PROGRAM KEGIATAN" dan memasukkan data pada form yang dipanggil. Untuk mengedit atau menghapus data pada form tersebut, pengguna dapat melakukan double click pada datagrid data yang ingin dihapus atau diedit. Tampilan form Program Kegiatan dapat dilihat sebagai berikut :

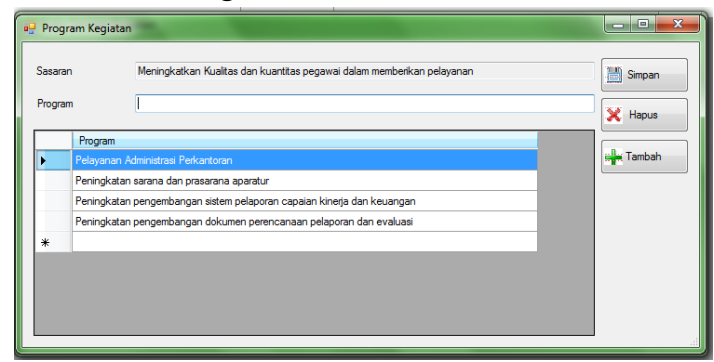

Gambar 22. Tampilan Form Program Kegiatan

\section{Form Indikator}

Form Indikator adalah form yang digunakan untuk mengolah data indikator dari rencana dan sasaran kerja Badan Kesatuan Bangsa dan Politik Kabupaten Murung Raya. Dalam form ini terdapat beberapa tombol, yaitu tombol Simpan untuk menyimpan data yang telah diinputkan, tombol Hapus untuk menghapus data dan tombol Tambah untuk menambah data. Untuk menghapus data pada form tersebut, pengguna dapat melakukan click pada datagrid data yang ingin dihapus kemudian memilih tombol Hapus. Tampilan form Data Indikator dapat dilihat sebagai berikut :

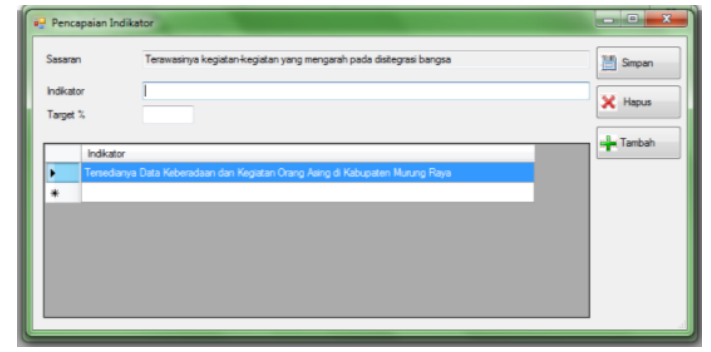

Gambar 23. Tampilan Form Indikator

\section{Form Pagu Indikatif Program}

Form Pagu Indikatif Program adalah form yang digunakan untuk mengolah data data pagu indikatif program kegiatan dari rencana kerja tahunan. Dalam form ini terdapat beberapa tombol, yaitu tombol Simpan untuk menyimpan data yang telah diinputkan, tombol Hapus untuk menghapus data dan tombol Tambah untuk menambah data. Untuk menghapus data pada form tersebut, pengguna dapat melakukan click pada datagrid data yang ingin dihapus kemudian memilih tombol Hapus. Tampilan form Pagu Indikatif Program dapat dilihat sebagai berikut :

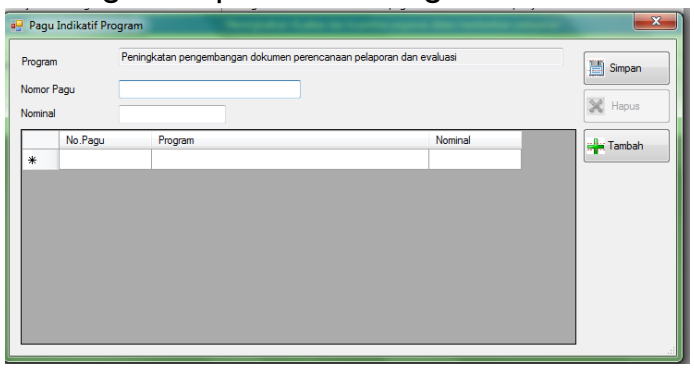

Gambar 24. Tampilan Form Pagu Indikatif Program

Berikut adalah tampilan form hasil cetak laporan data Pagu Indikatif Program yang dapat dilihat sebagai berikut :

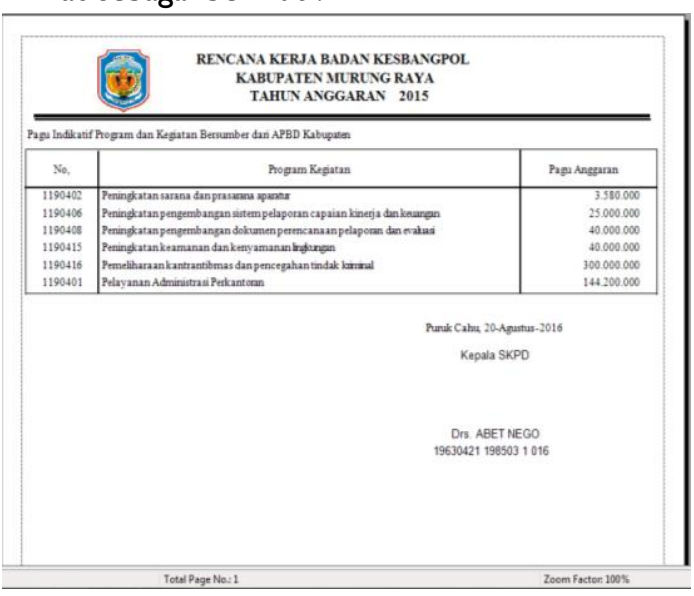

Gambar 25. Tampilan Cetak Laporan Data Pagu Indikatif Program

\section{Form Pencapaian Sasaran}

Form Pencapaian Sasaran adalah form yang digunakan untuk mengolah data pencapaian sasaran dari indikator rencana kerja Badan Kesatuan Bangsa dan Politik Kabupaten Murung Raya. Dalam form ini terdapat beberapa tombol, yaitu tombol Simpan untuk menyimpan data yang telah diinputkan, tombol Hapus untuk menghapus data dan tombol Tambah untuk menambah data. Untuk menghapus data pada form tersebut, 
Bayu Pratama Nugroho, Ferdiyani Haris dan Kristo Andri Anugrahno.

pengguna dapat melakukan click pada datagrid data yang ingin dihapus kemudian memilih tombol Hapus. Pencapaian sasaran (\%) dalam form ini akan terinput otomatis dari perhitungan target sasaran dan realisasi dengan rumus :

Realisasi $\times 100=$ Pencapaian Sasaran

Tampilan form Pencapaian Sasaran dapat dilihat seperti gambar berikut :

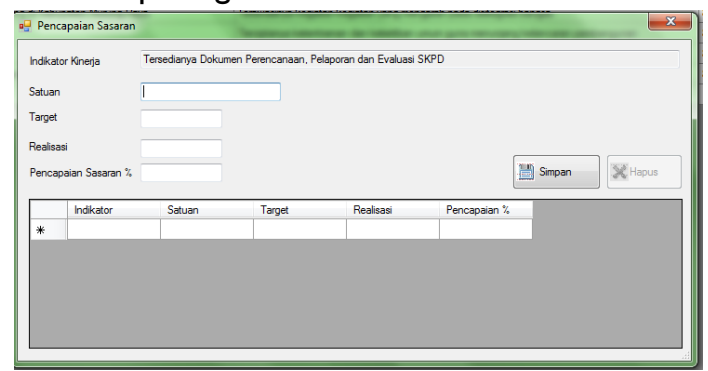

Gambar 26. Tampilan Form Pencapaian Sasaran

Berikut adalah tampilan form hasil cetak laporan data pencapaian sasaran yang dapat dilihat seperti gambar berikut :

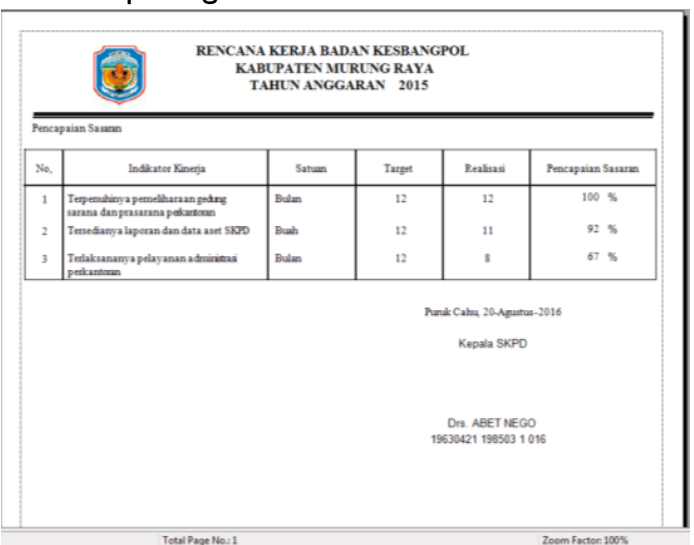

Gambar 27. Tampilan Cetak Laporan Data Pencapaian Sasaran

\section{Form Realisasi}

Form Realisasi adalah form yang digunakan untuk mengolah data realisasi anggaran kegiatan dari rencana kerja Badan Kesatuan Bangsa dan Politik Kabupaten Murung Raya. Dalam form ini terdapat beberapa tombol, yaitu tombol Simpan untuk menyimpan data yang telah diinputkan, atau menyimpan data yang sudah diedit dan tombol Hapus untuk menghapus data. Untuk menghapus data pada form tersebut, pengguna dapat melakukan click pada datagrid data yang ingin dihapus kemudian memilih tombol Hapus. Textbox "Sisa" dalam form ini akan terinput otomatis dari perhitungan Pagu Anggaran dikurangi Realisasi. Tampilan form Realisasi dapat dilihat seperti gambar berikut :

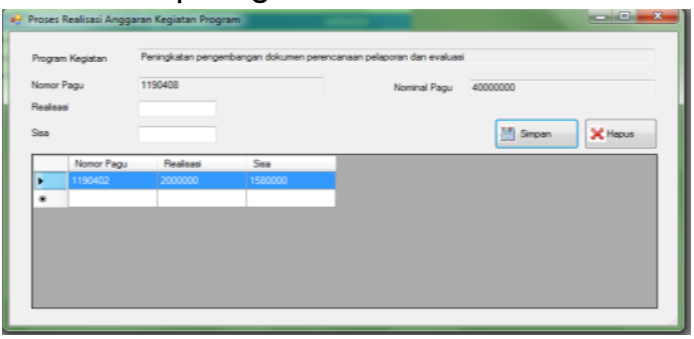

Gambar 28. Tampilan Form Realisasi

Berikut adalah tampilan form hasil cetak laporan data realisasi yang dapat dilihat sebagai berikut :

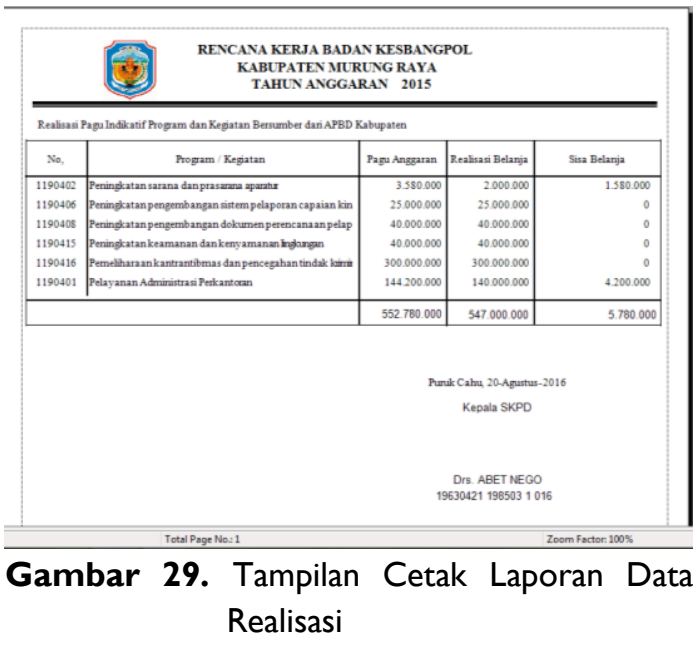

10. Form User

Form User adalah form yang digunakan untuk mengolah data Pengguna. Pengolahan tersebut meliputi penginputan username dan password pengguna serta mengatur hak akses pengguna terhadap sistem yang dibuat. Untuk tampilan form User dapat dilihat sebagai berikut : 


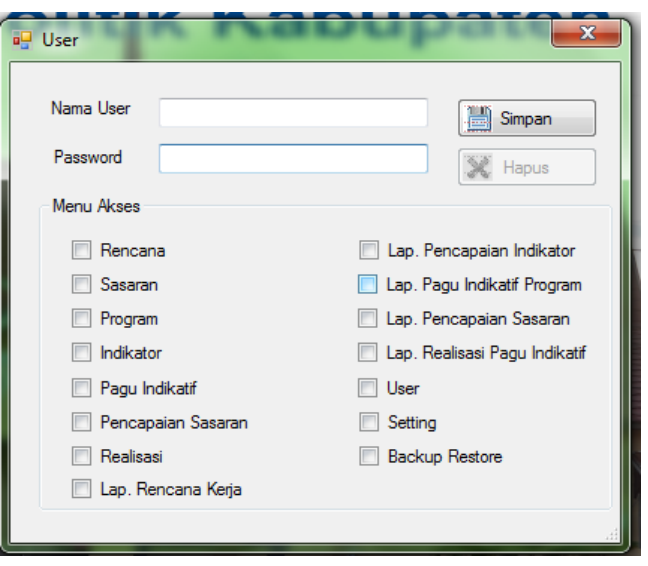

Gambar 30. Tampilan Form User

\section{KESIMPULAN DAN SARAN}

Pada penelitian ini telah berhasil dibuat dan diimplementasikan sebuah aplikasi Sistem Informasi Rancangan Kerja Tahunan pada Badan Kesatuan Bangsa dan Politik Kabupaten Murung Raya. Dengan adanya Sistem Informasi ini, maka proses manipulasi (tambah, edit \& hapus) pada data dilakukan dengan mudah dan cepat, sehingga pekerjaan para pegawai di Kantor dalam mengelola data rancangan kerja tahunan dalam segi kinerja profesionalnya meningkat. Dengan terkomputerisasinya sistem ini, maka memudahkan dalam proses pembuatan laporan rencana kerja tahunan pada Badan Kesatuan Bangsa dan Politik Kabupaten Murung Raya.

Penulis berharap Sistem Informasi ini dapat digunakan sebaik-baiknya dan memberikan manfaat yang lebih baik untuk para pegawai/staff yang berkerja di Badan Kesatuan Bangsa dan Politik Kabupaten Murung Raya. Diharapkan sistem informasi ini dapat membantu meningkatkan kinerja dan efisiensi dalam proses pelayanan kepada masyarakat.

\section{DAFTAR PUSTAKA}

A. S., Rosa dan Shalahuddin, M. 2018. Rekayasa Perangkat Lunak Terstruktur dan Berorientasi Objek. Bandung: Informatika.

Asmaranti, W., Andayani, S., 2018. Mengapa Media Berbasis Komputer dalam Pembelajaran Matematika Penting? Perspektif Guru dan Siswa. Jurnal Pendidikan Matematika dan Sains, VI (2), 2018, I46-157.
Bukhori, A., 20II, Analisis Dan Pengembangan Lanjutan Aplikasi Sireka (Sistem Informasi Rencana Kegiatan Dan Anggaran) Bagian Penyusunan Rencana Badan Pusat Statistik, Tugas Akhir, Program Studi Teknik Informatika, Fakultas IImu Komputer, Universitas Mercu Buana Jakarta.

Euis, A., 2016. Modernisasi Pembelajaran Di Perguruan Tinggi Berbasis Teknologi Informasi Dan Komunikasi, Judika (Jurnal Pendidikan Unsika), Vol. 4, No. 2, Hal. 185196.

Indarwati, I., 2013, Rancang Bangun Sistem Informasi Penyusunan Rencana Kerja Anggaran Pada Kelurahan Karangturi Gresik, Thesis, Universitas Dinamika.

Mayudho, I., Supriyanto, A., 2020. Penggunaan Pembelajaran Media Elektronik Untuk Pendidikan, Seminar Nasional Arah Manajemen Sekolah Pada Masa Dan Pasca Pandemi Covid-19.

Mumpuni, I., D., Dewa, W., A. 2017. Analisis Dan Pengembangan Sistem Self Services Terminal (Sst) Dengan Pendekatan Pieces Pada Stmik Pradnya Paramita Malang. Jurnal Ilmu Komputer dan Teknologi Informasi. Vol. 9, No. I.

Parsaorantua, P., H., Pasoreh, Y., Rondonuwu, S., A. 2017. Implementasi Teknologi Informasi Dan Komunikasi (Studi Tentang Web E-Government Di Kominfo Kota Manado). e-journal Vol. VI. No. 3.

Pratiwi, T., Widodo, S., Kanthi, Y. A., 2018, Sistem Informasi Penyusunan Rencana Kerja Pemerintah (RKP) Desa Bidang Pembangunan Infrastruktur Berbasis Web (Studi Kasus : Desa Pandanlandung Kecamatan Wagir Kabupaten Malang). SYSTEMIC : Information System and Informatics Journal, Vol. 4, No. 2, pp. 30-35 